\title{
HOW DO WORKAHOLICS EXPERIENCE WORKING? ${ }^{1}$
}

\author{
RONALD J. BURKE \\ Prof.Dr.,York University \\ STIG BERGE MATTHEISEN \\ University of Bergen
}

\begin{abstract}
This exploratory study examined the relationships of workaholism components identified by Spence and Robbins (1992) and the experience of flow or optimal experience among 211 journalists in Norway. Data were collected using anonymous questionnaires. Three workaholism components were considered: work involvement, feeling driven to work because of inner needs, and work enjoyment. Hierarchical regression analyses, controlling for personal demographics and work situation characteristics, found that journalists scoring higher on work enjoyment and lower on feeling driven to work indicated higher levels of flow or optimal experience at work.
\end{abstract}

Keywords: Workhaholic, Journalist, Work Involvement

\section{INTRODUCTION}

Some writers have suggested that workaholics approach their jobs or work differently than do non-workaholics. Workaholics are addicted to, obsessed with, and driven to work because of internal needs, not external organization demands (Fassel, 1990; Killinger, 1991; Oates, 1971; Porter, 1996). The motivations for working long hours tend to be self-protective or negative (Robinson, 1998). It has also been shown that workaholics are more perfectionistic, have greater difficulty in delegating work to others, encounter more conflict and tension in their interpersonal relationships and report higher levels of

${ }^{1}$ This research was supported in part by the Department of Psychology, University of Bergen and the School of Business, York University. Lisa Fiksenbaum assisted with data analysis. We thank Janet Spence for permission to use her measures 
work stress than do non-workaholics (see Burke, 2000, and McMillan, O'Dricoll \& Burke, 2003, for reviews).

There is accumulating research evidence that support some of these conclusions. Burke (1999a) found, using the Spence and Robbins workaholism types (1992), that Work Addicts scored higher on a measure of beliefs and fears than did both Work enthusiasts and Enthusiastic Addicts. This measure taps aspects of a self-protective or negative motivation such as the need to prove oneself, the need to achieve materialistic trappings of success to feel a sense of worth, and belief that the world is a "dog eat dog", zero-sum game. Work addicts scored higher than Work Enthusiasts and Enthusiastic Addicts on measures of perfectionism, non-delegation and job stress as well (Burke, 1999a; Spence \& Robbins, 1992).

Some researchers have proposed the existence of different types of workaholic behavior patterns, each having potentially different antecedents and associations with job performance, work and life outcomes, (Naughton, 1987; Scott, Moore \& Miceli, 1997; Spence \& Robbins, 1992). Naughton (1987) presents a typology of workaholism based on the dimensions of career commitment and obsessioncompulsion. Job-involved workaholics (high work commitment, low obsession-compulsion) are hypothesized to perform well in demanding jobs, be highly job satisfied with low interest in non-work activities.

Scott, Moore and Miceli (1997) propose three types of workaholic behavior patterns: compulsive-dependent, perfectionist and achievement-oriented. They suggest that compulsive-dependent workaholism will be positively related to levels of anxiety, stress, physical and psychological problems and negatively related to job performance and job and life satisfaction. Perfectionist workaholism will be positively related to levels of stress, physical and psychological problems, hostile interpersonal relationships, low job satisfaction and performance and voluntary turnover and absenteeism. Finally, achievement-oriented workaholism will be positively related to physical and psychological health, job and life satisfaction, job performance, low voluntary turnover and pro-social behaviors.

Spence and Robbins (1992) identified three workaholism components based on an extensive review of the literature: work involvement, feeling driven to work and work enjoyment. Profile analysis of scores on these components indicated three workaholic types. Work Addicts score high on work involvement and feeling driven to work and low on work enjoyment. Work Enthusiasts score high on work involvement and work enjoyment and low on feeling driven to 
work. Enthusiastic Work Addicts score high on all three components. They then offer a number of hypotheses as to how these three workaholic patterns might differ from each other. Thus, Work Addicts would be more perfectionistic, would experience greater stress and report more physical health symptoms. The existence of different types of workaholic patterns might help reconcile conflicting observations and conclusions cited above. Most writers view workaholism as a stable individual characteristic (Scott, Moore \& Miceli, 1997; Spence \& Robbins, 1992).

The present study examines the question of how workaholics experience working and their work. More specifically, it examines the relationship of workaholism types and the experience of flow at work. Csikszentmihalyi coined the term flow in 1990 (Csikszentmihalyi, 1990). Csikszentmihalyi notes that happiness depends on people's engagement in tasks and their working toward goals. He suggests that individuals are not happy because of what they do but because of how they do it, the process of an activity.

Csikszentmihalyi (1990) uses the term optimal experience to refer to times when individuals feel in control of their actions and masters of their own destinies. Optimal experiences commonly result from hard work and meeting challenges head on. Individuals make optimal experiences happen. Optimal experiences contribute to a sense of mastery, of participating in the events of one's life. Csikszentmihalyi developed a theory of optimal experience based on the concept of flow, a state in which individual's become so involved in an activity that nothing else matters.

Csikszentmihalyi believes that since so much time is invested and spent in working, the experience of flow at work is likely to have significant effects on one's quality of life (Csikszentmihalyi, 1997). Flow also plays major role in how people respond to stress. Csikszentmihalyi reports data showing that women and men experience more flow at work than in leisure (Csikszentmihalyi, 2003). He also reports that managers and supervisors were more often in flow at work (64 per cent) than were clerical workers (51 per cent) and blue collar workers (49 per cent). Apathy was reported at work more often by blue collar workers than managers (23 versus 11 per cent), and in leisure more often by managers than by blue collar workers (61 versus 46 per cent). Certain activities are more conducive to flow as they make optimal experience easier to achieved (e.g., learning skills, goals and new solutions (Seligman \& Czikszentmihaly, 2000). 
Clawson (1999) identifies resonance as the key underlying superior performance, even world class performance, in any field of endeavour. Resonance is a special type of experience that high level performance in a chosen valued field brings to an individual. People who perform at their best report a common experience. Professional athletes refer to it as 'being in the zone', jazz musicians refer to it as 'being in the groove', managers use the term 'resonance' to capture these experiences.

The general hypothesis underlying this research in that the experience of flow at work would be related to particular workaholism components, more specifically positively to work enjoyment and negatively to feeling driven to work. A research model was developed to both guide selection of variables to be included and data analysis (see Figure 1). Three blocks of predictors were considered. The first block were personal demographics such as age, gender and level of education. The second block included work situation characteristics such as unit size, tenure as a journalist and whether respondent had supervisory responsibilities. These two blocks of variables served as control variables before examining the relationship of the third block of predictors, the three workaholism components, on the measure of flow.

Method

\section{Respondents}

Data were collected from 211 journalists working in the city of Bergen Norway. Table 1 shows the demographic characteristics of the sample. Two thirds of the sample were male $(67 \%)$, most were married $(70.4 \%)$, worked in permanent jobs $(89.4 \%)$, were under 40 years of age $(65.1 \%)$ worked between 31 and 40 hours per week $(55.0 \%)$, had relatively low levels of job and organizational tenure $42.1 \%$ had 44 years or less organizational tenure and $46.2 \%$ had 2 years or less job tenure and most had no supervisory responsibilities $(74 \%)$. Table 1

\section{Procedure}

Data were collected from 211 journalists using anonymously completed questionnaires, representing a response rate of forty-three percent. Five hundred questionnaires were mailed out by the journalists union; completed questionnaires were returned to a university address. Measures originally appearing in English were translated into Norwegian by members of the research team (e.g., flow); other measures (e.g., Spence and Robbins workaholism components) had 
already been translated into Norwegian from English and used in previous research projects.

\section{Measures}

\section{Workaholism Components}

Spence and Robbins (1992) derive three workaholism components on the basis of an extensive literature review: work involvement, feeling driven to work and work enjoyment. Their measures were used in this study. Work involvement $(\propto=.67)$ had eight items (e.g., "I get bored and restless on vacations when I haven't anything productive to do"). Feeling Driven to Work $(\propto=.80)$ had seven items (e.g., "I often feel that there's something inside me that drives me to work hard"). Joy in work ( $\propto=.88$ ) had ten items (e.g., "My job is more like fun than work").

\section{Flow}

Optimal experience or flow was measured by a 36 item instrument developed and validated by Jackson and Marsh (1996). Nine dimensions of flow were identified from previous writing (Csikzentmihalyi, 1990; Jackson, 1995). These were: challenge-skill balance, action- awareness merging, clear goals, unambiguous feedback, concentration on the task at hand, paradox of control, loss of self-consciousness, the transformation of time and an autotelic (enjoyable) experience. Each was measured by four items: Respondents indicated their agreement with each item on a 5-point scale $(1=$ strongly disagree, $3=$ neither agree nor disagree, $5=$ strongly agree). Sample items included: "My abilities matched the high challenge of the situation". "It felt like time stopped while I was working". A measure of total flow was created by combining scores on the none subscales since all were positively and most significantly intercorrelated $(\alpha=.89)$.

\section{Results}

\section{Descriptive Statistics}

Table 2 presents the means, standard deviations sample sizes and intercorrelations among all measures used in the study. The following comments are offered in summary. First, considering the personal demographics, older journalists reported greater feeling driven to work and flow respectively $\left(r_{s}=.18\right.$ and $.18, p_{s}<.01$ and .05$)$. Men 
scored higher on feeling driven than did women $\left(r=.18, p_{s}<.05\right)$ and married journalists scored higher on feeling driven than did single journalists $(r=.16, p<.05)$. The correlations between personal demographics and both workaholism components and the experience of flow were inconsistent and small, none exceeding .30. Second, considering the correlations between the five work situation characteristics and the workaholism components and the measure of flow, a somewhat similar pattern existed. No correlation exceeded .25; both editorial group size and income had significant relationships with three of the four outcome variables. Journalists working in larger editorial groups were less work involved, less driven and reported higher levels of flow; journalists earning greater incomes were more driven, experienced less work enjoyment and higher levels of flow. Third, considering the three workaholism components, journalists scoring higher on work involvement also reported higher feeling driven to work and higher work enjoyment $\left(r_{s}=.23\right.$ and .17, $p<.001$ and $p<$ .01 , respectively). Fourth, journalists scoring lower on feeling driven to work and higher on work enjoyment also indicated higher levels of flow at work $\left(r_{s}=-.20\right.$ and $.34, p<.01$ and $p<.001$, respectively). Table 2

\section{Predictors of flow}

Hierarchical regression analysis were used to examine the research model (see Figure 1). Blocks of predictors were entered in the order shown in Figure 1 permitting an examination of the relationship of workaholism components with the experience of flow controlling the effect of both personal demographic and work situation characteristics. When a block of predictors accounted for a significant amount or increment in explained variance on the measure of flow, measures within such blocks having independent and significant relationships with the measure of flow were identified. Table 3 shows the results of this analysis using the measure of total flow. Findings were essentially identical on each of the nine flow elements.

The following comments are offered in summary. First, neither block of personal demographic or work situation characteristics accounted for a significant amount or increment in explained variance on the measure of total flow. Second, workaholism components accounted for a significant increment in explained variance on the measure of flow with two components having independent and significant relationships with the flow experience. Journalists reporting 
less feeling driven to work and more work enjoyment also indicated higher levels of total flow ( $\beta s=-.23$ and .37 , respectively)..

\section{Discussion}

Why should there be an association between workaholism components and the experience of flow? Czikszentmihalyi (2003) has written that some individuals that work long hours are able to experience flow (the Work Enthusiasts) while others are not (the Work Addicts). Work enjoyment would be high in the former and feeling driven in the latter.

Other work has shown that individuals scoring high on work enjoyment also report greater job and career satisfaction and less intention to quit (Burke, 2001; Spence \& Robbins, 1992). Individuals scoring higher on feeling driven to work also indicated more psychological distress (Burke, 1999b; Spence \& Robbins, 1992). In addition, managers and professionals scoring higher on feeling driven also endorsed more strongly measures of beliefs and fears reflecting the need to prove oneself through materialism (Burke, 1999a).

Thus, both work motivation (who) and the way that work is approached (how) may help explain the workaholism - flow relationship. Work addicts indicate greater perfectionism, more difficult delegating work to them and higher levels of job stress (see Burke, 2000; McMillan, O'Driscoll \& Burke, 2003) for reviews.

Czikszentmihalyi (2003) suggests that when individuals see themselves as experienceing above average levels of both challenge and skill utilization, they will experience flow. High anxiety, associated with workaholism (see Robsinson, 1998; Porter, 1996) is proposed by Czikszentmihalyi to exist when challenge is seen as high and skills as low, reflecting perhaps the insecurity and low self-esteem associated with workaholism.

The study of flow in organizations has received relatively little research attention. Cziksezentmihalyi (2003) undertook a qualitative interview study with 39 business leaders nominated because they combined high achievement with a strong moral commitment. It is easy to understand why and how these individuals might experience flow. Their jobs involved high levels of meaning, personal control, freedom and challenge. Is the concept of flow relevant to lower level and less skilled employees?

There are several reasons why flow does not happen at work. Many job lack clear goals. Many jobs do not provide feedback to the 
employee on how they are doing. In addition, employee skills are often not well matched to the jobs they are holding. Many workers have little or no control over their work processes. Finally, work is devalued in many societies as leisure and relaxation are praised. It is difficult to experience flow if employees believe their jobs contribute little of value or meaning.

It is important to undertake research that contributes to a greater understanding of flow in organizations. This should increase our ability to build flow in organizations.

Cziksezentmihalyi makes a start here. Senior management must believe that they need to be responsible for contributing to the emotional well-being of their employees. Then the mission of their organizations must few made clear to all. Job responsibilities must be spelled out and feedback on performance and accomplishments available to all. Training and development needs to be available to balance challenges and skills. Work interruptions should be kept to a minimum. Employees need to have as much control over their work processes as possible. It is possible for all individuals to experience flow at both work and in life in general under the right conditions.

\section{Limitations of the Study}

Some limitations of the study need to be noted to help put the findings in a larger context. First, all data were collected using questionnaires opening up the possibility of response set consistencies. Second, the data was collected at one point in time making it impossible to address issues of causality. Third, it is not clear the extent to which these findings would generalize to other occupational groups in other countries. 


\section{References}

Burke, R.J., (1999a) Workaholism in organizations: The role of personal beliefs and fears. Anxiety, Stress and Coping, 13, 1-12.

Burke, R.J. (1999b) Workaholism in organizations. Measurement validation and replication. International Journal of Stress Management, 6, 45-55.

Burke, R.J. (2000) Workaholism in organizations: Concepts, results and future directions. International Journal of Management Reviews, 2, 1-16.

Burke, R.J. (2001) Workaholism components, job satisfaction, and career progress. Journal of Applied Social Psychology, 31, 2339-2356.

Clawson, J.G. (1999) Level three leadership: Getting below the surface. Upper Saddle River, NJ: Prentice Hall.

Csikszentmihalyi, M. (1990) Flow: The psychology of optimal experience. New York: Harper Collings.

Csikszentmihalyi, M. (2003) Good business New York: Viking

Csikszentmihalyi, M. (1997) Finding flow: The psychology of engagement with everyday life. New York: Basic Books.

Fassel, D. (1990) Working ourselves to death: The high costs of workaholism, the rewards of recovery. San Francisco, CA: Harper Collins.

Jackson, S.A. \& Marsh, H.W. (1996) Development and validation of a scale to measure optimal experience: The Flow State Scale. Journal of Sport \& Exercise Psychology, 18, 17-35.

Jackson, S.A. (1995) Factors influencing the occurrence of flow state in elite athletes. Journal of Applied Sport Psychology, 7, 138-166.

Killinger, B. (1991) Workaholics: The respectable addicts. New York: Simon \& Schuster.

McMillan, L.H.W., O'Driscoll, M.P. \& Burke, R.J. (2003) Workaholism: A review of theory, research and new directions in C.L. Cooper \& I.T. Robertson (eds.) International Review of Industrial and Organizational Psychology, New York: John Wiley, pp. 167-190.

Naughton, T.J. (1987) A conceptual view of workaholism and implications for career counseling and research. The Career Development Quarterly, $14,180-187$. 
Oates, W. (1971) Confessions of a workaholic: The facts about work addiction. New York: World.

Porter, G. (1996) Organizational impact of workaholism: Suggestions for researching the negative outcomes of excessive work. Journal of Occupational Health Psychology, 1, 70-84.

Robinson, B.E. (1998) Chained to the desk: A quidebook for workaholics, their partners and children and the clinicians who treat them. New York: NYU Press.

Scott, K.S., Moore, K.S., \& Miceli, M.P. (1997) An exploration of the meaning and consequences of workaholism. Human Relations, 50, 287-314.

Seligman, M.E.P. \& Czikszentmihalyi, M. (2000) Positive psychology: An introduction. American Psychologist, 55, 56-57.

Spence, J.T. \& Robbins, A.S. (1992) Workaholism: Definition, measurement, and preliminary results. Journal of Personality Assessment, 58, 160-178 